\title{
Effect of stocking density in polyculture system on growth performance of cultured Fish and productivity in Earthen Ponds.
}

\author{
Nabil, F. Abdel- Hakim ${ }^{1}$; Ahmed, M. Zaglul ${ }^{1}$ and Mahmud, H. Awad ${ }^{2}$ \\ 1- Department of Animal Production, Faculty of Agriculture, Al-Azhar University, Cairo, \\ Egypt. \\ 2- General Authority for Fish Resources Deveolopment Kafr El-Sheirh
}

\section{ABSTRACT}

The present study was carried out in a private fish farm located in the area of Tolompat 7, Riyad, Kafr El- Sheikh Governrate, Nile Delta district, Egypt. The study aimed to evaluate the effect of stocking density of different fish species on growth performance, feed, conversion, chemical body composition and economic efficiency. Three stocking densities in replicates each of one Feddan area were arranged in the present study. The first stocking density was the traditional stocking density in the study area (16000 fish/Feddan) ( $\left.\mathrm{T}_{1}\right)$ (12000 Nile Tilapia Oreochromis niloticus + 3000 Tobara Liza ramada +1000 Bouri Mugel cephalus). The second treatment included the stocking density 19200 fish/Feddan ( $\mathrm{T}_{2} 14400$ Ttilapia +3600 Tobara + 1200 Bouri) and the third (T3) treatment was stocked with 22400fish /feddan (16800 Tilapia +4200 Tobara +1400 Bouri). Each treatment was carried out in replicates each of one Feddan $\left(4200 \mathrm{~m}^{2}\right)$ area and study lasted 24 weeks from the start. The initial weights of the experimental fish were $25 \mathrm{~g}, 10 \mathrm{~g}$. and $15 \mathrm{~g}$. for Tilapia; Tobara and Bouri, respectively. The experimental fish were fed on a diet containing $25 \%$ protein at a rate of $3 \%$ \& the fish biomass daily. The diet was offered in two portions at 10.00am.and $2.00 \mathrm{pm}$ daily then fish samples were taken from each pond every 15 days to calculate the feeding rate for the next period. Water quality parameters were determined every two weeks. Water dissolved oxygen and $\mathrm{pH}$ were determined twice weekly. Results obtained are summarized in the following:

1- Averages of final weights of Tilapia decreased significantly with each increase in the stocking density and the same trend was observed with total weight gain and relative growth.

2- Final body weight, total weight and gain and relative growth rate of Bouri and Tobara rate decreased significantly with each increase in the stocking density.

3- Stocking density released significant differences in dry matter, protein NFE and gross energy contents of tilapia whole bodies. On the other hand, stocking density released significantly differences in whole body composition parameters of Bouri and Tobara.

4- Feed conversion ratio (kg. of feed required for each kg. /gain in weight) increased with each increase in the stocking density.

5- Water quality parameters including water temperature, dissolved oxygen, $\mathrm{pH}$ value, total ammonia, nitrate, nitrite and salinity, were within the permissible levels required for the tested species.

6- Total fish yield kg. /feddan increased significantly with each increase in the stocking density.

7- Percentages of net returns over costs for T1, T2 andT3 were 50.59, 44,97, and $12.92 \%$,respectively indicating the most profiTable stocking density of tilapia and Bouri and Tobara lie between 16000 and 19200 fish /feddan. 
Based on the obtained results, a stocking density of 16000 fish /feddan (1200 tilapia +300 Tobara +1000 Bouri) is recommended in the study area for higher profit. Increasing thestocking density may require frequent pond water exchange and intensive water aeration and higher feeding rates.

Keywords: Stocking density; Nile tilapia, Mullet species growth parameters, pond fish yield

\section{INTRODUCTION}

The total fish production from all resources in Egypt during (2012) was estimated by 1371975 tons (GAFRD, 2012) and all aquaculture activities contributed by 1017738 tons during the same year which represented about $74.18 \%$ of the total national fish production. During 2012 Egypt imported 335023 tons (GAFRD, 2012) to increase the fish per capita consumption in the country from 16.48 to $20.55 \mathrm{~kg} /$ year. The facts mentioned above reflect the importance of aquaculture activities in securing the fish protein demand for Egyptian people. Because of the limited fresh water resources required to increase the production of fresh water fish species (Tilapia, Mullets and Carp species) it is necessary to develop system to increase the production of fish vertically by performing new methods concerned with fish feeding, fish cultured species and the fish stocking density.

Applying the developed method in aquaculture activities could help the fish farmer to increase his production vertically per unit area. In aquaculture, 'stocking density' should denote the concentration at which fish are initially stocked into a system. However, it is generally used to refer to the density of fish at any point of time. It is considered to be one of the important factors that affect fish growth, feed utilization and gross fish yield (Liu and Chang, 1992). The full utilization of space for maximum fish production through intensive culture can improve the profitability of the fish farm. Fish intensification by increasing stocking density was also found suiTable to overcome the problem of land shortage (Khattab et al., 2004; Chakraborty and Banerjee, 2010). Chang (1988) reported that fish stocking density is an important factor used in aquaculture as it can affect natural food availability, the efficient utilization of food resource and total fish yield in ponds. polyculture of fish is usually used to combine omnivorous tilapia sp. with benthphagic mullet sp. to take advantage of various feeding pond riches (Malecha et al., 1981). In addition, the polyculture aims to increase productivity by a more efficient utilization of the ecological resources in the aquatic environment (Lutz, 2003). When the concentration of different species are adequate in the polyculture pond, the growth rate of plankton, macrophytes benthos and nekton (other than the stocked fishes) keep pace with the rate of consumption by the cultured fisher (Bíró, 1995). The objective of the present study were to evaluate the effects of increasing stocking densities of Tilapia Tobers and mullet species reared in polyculture system in earthen ponds on growth performance. Feed utilization plankton abundance gross yield and profitability under the Egyptian conditions.

\section{MATERIALS AND METHODS}

\section{Location of the experimental ponds:}

The present study was carried out in aprivate fish farm located in the area of Tolombat 7, Riyad, Kafr El-Sheikh governorate, Delta district at the Northern part of Egypt. The study aimed to evaluate the effect of stocking density of different fish 
species on growth performance, feed utilization, chemical body composition and economic efficiency. The study was perfarmed in 6 earthen ponds representing three stocking densities in douplicates.

\section{Experimental design.}

The present experiment was conducted using a complete randomized block design for three treatments with two replications of each treatment. The experimental treatment with replicates were applied in earthen ponds, each of one feddan area $\left(4200 \mathrm{~m}^{2}\right)$. The three stocking densities tested were (T1) 16000 fish / feddan (12000 Nile tilapia + 3000 Tobara + 1000 Bouri); (T2) 19200 fish / feddan (14400 Nile tilapia +3600 Tobara +1200 Bouri) and (T3) 22400 fish / feddan (16800 Nile tilapia + 4200 Tobara +1400 Bouri) .The T1 was considered as control (standard) and T2 was stocked with $20 \%$ of fish number over T1 and T3 was stocked with $40 \%$ of fish number over T1. The treatments are illustrated in the following Table (1).

Table 1: The experimental design and number of fish / pond .

\begin{tabular}{|c|c|c|c|}
\hline Fish species & T1 & $\mathrm{T} 2$ & T3 \\
\hline $\begin{array}{l}\text { Nile tilapia(Oreochromis niloticus) Grey mullet } \\
\text { (Liza ramada) Topara } \\
\text { Mullet (Mugil cephalus) Bouri. }\end{array}$ & $\begin{array}{l}12000 \\
3000 \\
1000\end{array}$ & $\begin{array}{l}14400 \\
3600 \\
1200\end{array}$ & $\begin{array}{l}16800 \\
4200 \\
1400\end{array}$ \\
\hline$\%$ of stocking density on $\mathrm{T} 1$ & 100 & 120 & 140 \\
\hline
\end{tabular}

\section{Ponds description and preparation.}

The experimental ponds of the present study were equal in the whole area water volume $\left(4200 \mathrm{~m}^{2}\right)$ each with the same average depth of $1.5 \mathrm{~m}$. Perior to the experimental start all ponds were completely drained, de weeded and the ponds bottom was exposed to sun rays for one month for complete dryness. Each pond was provided with an inlet and outlet water (pipes) gates covered with narrow mesh screens to prevent entrance of forgein unwanted fish or predators and escaping af the cultured fish species. The water level was kept at $150 \mathrm{~cm}$.

Water depth and water level was controlled through the gates. Ponds watar was experimented at a rate of $30 \%$ daily and replaced with new water.

The farm water source was mainly agricultural drainage water from Tolombat 7 drainage canal.

Ponds were fed with water using pumps while drainge was maintained by gravity. After complete dryness of the experimental Ponds were filled with the water and after four days the experimental fish were stocked.

Experimental fishes and feeding practice:

\section{Fish species.}

Three fish species were used in the present study, the first was Nile tilapia (Oreochromis niloticus), the second wasTobara (Liza ramada) and the third was the Bouri (Mugil cephalus). Nile tilapiamono sex fingerlings fry were purchased from a private fish hatchery in Kafr El-Sheikh in August 2012 and nursed in nursery ponds at the experimental ponds till April 2013 then transferred to the experimental grow out ponds with an initial body weight of $25 \mathrm{~g} /$ fish on the average. Tobara fry were purchased from fry collection station in Dimiitta in January 2013 and reared in nursery ponds till April 2013 then transferred to the grow out experimental ponds with an average initial weight of $10 \mathrm{~g}$ Bouri fry were obtained from fry collection station in max (Alexandria) and from Dimiitta Governorate, in July 2012 and nursed till the first of April 2013 then transferred to grow out experimental ponds with initial weight of $15 \mathrm{~g}$. 


\section{Feeding pratice}

The fish in the three tasted stocking densities were fed during the whole experimental period (24 weeks) on a commercial fish diet containing $25 \%$ crude protein and $3580 \mathrm{Kcal} / \mathrm{kg}$ gross energy (Table 2). The ingredients of the diet were fish meal, soybean meal, fish oil, yellow maize, cotton seed meal, minerals and vitamins mixtures.

The fish in the three tasted stocking densities were fed on the commercial diet six days per week at feeding rate of $3 \%$ of the fish biomass. The daily diet was broadcasted at different places of the pond per hand twice daily at 10.00 am and 2.00 pm during the whole experimental period.

Fish samples were with drown bi-weekly (30 fish each species each treatment) and weighed to readjust the feeding rate was readjasted according the new weights. Fish sample were returned back to the corresbonding treatments after recording the body weight and body length.

\section{Experimental ponds}

The present study was conducted in six earthen ponds of equal area of one feddan each. The average water depth was $150 \mathrm{~cm}$. All ponds were longitudinal in shape (50x $83 \mathrm{~m}$ ) with a total water surface area of $4150 \mathrm{~m}^{2}$ ).

Table 2: Composition and proximate chemical analysis of the experimental ration.

\begin{tabular}{|l|l|}
\hline Item & \%Ration \\
\hline Fish meal & 19.55 \\
Soybean meal & 12.85 \\
Fish oil & 6.50 \\
yellow maize & 38.60 \\
Cottonseed meal & 16.50 \\
Minerals mix. $^{2}$ & 4.00 \\
Vitamins Mix. $^{2}$ & 2.00 \\
\hline Total & 100 \\
\hline Proximate analysis (\% of dry weight) & \\
\hline Moisture & 19.50 \\
Dry matter & 89.65 \\
Crude protein & 24.95 \\
Ether extract & 6.50 \\
Ash & 11.50 \\
Crude fiber & 20.50 \\
$*$ Nitrogen free extract & 36.55 \\
$* *$ Gross energy (Kcal/kg) & 3580 \\
\hline
\end{tabular}

1-Mineral premix (as g/kg premix): $\mathrm{CaHPO}_{4} \cdot 2 \mathrm{H}_{2} \mathrm{O}$ 727.7775; $\mathrm{MgSO}_{4}$. $\mathrm{H}_{2} \mathrm{O}$ 127.5; Kca l50.0; Na Cl 60; Fe $\mathrm{SO}_{4} .7 \mathrm{H}_{2} \mathrm{O} 25 ; \mathrm{ZnSO}_{4} .7 \mathrm{H}_{2} \mathrm{O} 505 ; \mathrm{MnSO}_{4} .4 \mathrm{H}_{2} \mathrm{O}$ 2.53; Cu SO $4.50785 ; \mathrm{CoSO}_{4} .7 \mathrm{H}_{2} \mathrm{O}$ 0.4775; Ca $\mathrm{LO}_{3}$. $6 \mathrm{H}_{2} \mathrm{O}$.295; $\mathrm{Cr} \mathrm{CL}_{3}$. $6 \mathrm{H}_{2} \mathrm{O} 0.1275$.

2-Vitamins mixture contained (as g/kg premix): Thiamine 2.5; Riboflavin 2.5; pyridoxine 2.0; Inositol 100.0; Biotin 0.3; Pantothenic acid 100.0; folic acid 0.75; Para-aminobenzioic 2.5; Choline 200.0; Nicotinic acid 10. Cyanocobalmine 0.005; Tocopherol acetate 20.1; Ascorbic acid 50.0; Menadione 2.0; Retinol palmitate 100.000 IU; Cholecalciferol 500.000 IU.

*Nitrogen Free Extract calculated as: 100-\% (Protein + Lipid + Ash + Crude fiber).

**GE ( gross energy) calculated using the values 4.1 , 5.6 and 9.44 Kcal GE/g DM of carbohydrate , protein and fat, respectively (NRC, 1993).

Before the experimental start, all ponds were completely drained, de weeded and the ponds bottom was exposed to sun rays for one month for complete dryness. Thereafter, ponds dried soil was ploughed and flated. Each pond had an water inlet and water outlet gates through which the water level was controlled. The farm water source was mainly agricultural drainage water, coming from Tolombat 7 main drainage canal. Ponds inlet and outlet pipes were covered with narrow mesh screen to 
prevent unwanted fish or predators to enter into ponds or escaping of the cultured fish. ponds watar was exchanged daily at a rate of $30 \%$ using water pumps, while ponds water was drained by gravtit. Five days perior to fish syocking ponds were filled to the level of $75 \mathrm{~cm}$ these the experimental fish were stocked and thereafter water ievel was increased to reach the maximum target colum of $150 \mathrm{~cm}$.

\section{Pond management}

The trial lasted for 180 days started at the $1^{\text {st }}$ of April and harvested at $30^{\text {th }}$ September 2012.

\section{Water management}

Diely water inlet pipes were adjusted to allow fresh water to flow into ponds to compensate water loss through evaporation, seepage and to maintain water level in pond throughout the experimental period. Integrated water samples were taken every 15 days, analyzed for $\mathrm{pH}$, dissolved oxygen (DO), temperature, salinity, nitrte, natrate-nitrogen and total ammonia analysis during growing period at 9.00 to 9.30 am).

\section{Fish harvest}

Fish yield was collected and sorted according to size for marketing (Table 3).

Table 3: Size grades of tilapia fish species at harvest.

\begin{tabular}{|l|l|l|l|l|}
\hline Size Grade & Super & $1^{\text {st }}$ grade & $2^{\text {nd }}$ grade & $3^{\text {rd }}$ grade \\
\hline Weight(g) & $>250$ & $250-200$ & $200-150$ & $<150$ \\
\hline
\end{tabular}

For mullets the following grades were consitered for markting (Table 4). Fish yield of each size class was weighed and counted then the survival rate was calculated.

Table 4: Size grades of tobara fish at harvest.

\begin{tabular}{|l|l|l|}
\hline Size Grade & $1^{\text {st }}$ grade & $2^{\text {nd }}$ grade \\
\hline Weight(g) & $300-250$ & $<250$ \\
\hline
\end{tabular}

\section{Analytical procedures \\ Water quality measurements}

Each fifteen days water samples were collected from each of the experimental ponds for measuring some physico-chemical parameters. The samples were collected from three fixed places at each pond, then mixed together to form a composite sample. The samples were analyzed within few hours after collection. Some parameters such as temperature, $\mathrm{pH}$ and dissolved oxygen were measured a the expermental ponds. Five milliters of chloroform were added to each bottle sample as a preservative.

\section{Dissolved oxygen and temperature}

Dissolved Oxygen (DO mg/L) and temperature $\left({ }^{\circ} \mathrm{C}\right)$ were measured in pond water (between 9.00 to $9.30 \mathrm{am}$ ) weekly using Thermo Orion (model 835A, Orion Research Inc) oxygen meter.

\section{Laboratory analysis}

A sample of water (1litre) from each pond was taken (at 9.00 to $9.30 \mathrm{am}$ ) weekly and transferred to the laboratory for the following measurements: pH values.

$\mathrm{pH}$ values were measured using $\mathrm{pH}$ meter model 3050 Jenway electrochemical products, range from 0 to 14 . 


\section{Total ammonia $\left(\mathrm{NH}_{4}-\mathrm{N}\right)$.}

Ammonia test kits Hanna Instruments (HI) 4829 kit range from 0-2.5 mg $\mathrm{NH}_{4}$ $\mathrm{N} / \mathrm{L}$ were used to estimate the concentration of the total ammonia in water samples (APHA, 1998).

\section{Nitrate $\left(\mathrm{NO}_{3}-\mathrm{N} \mathbf{~ m g} / \mathrm{L}\right)$.}

Nitrate-nitrogen was measured by using phenoldisulphonic acid method, using spectrophotometer (Model Milton Roy 21D), at a wavelength of $410 \mathrm{~nm}$ (APHA, 1998).

\section{Nitrite $\left(\mathrm{NO}_{2}-\mathbf{N} \mathbf{m g} / \mathrm{L}\right)$.}

Nitrite was measured by (nitricol) model LP-55 code 3274 Lamotte company range from 0.2-0.8 ppm

\section{Salinity.}

Conductivity meter model 4070 Jenway elctrochemical product was used to determine salinity in water samples as ppt/ L.

\section{Measurements of fish growth and production parameters.}

At the end of the experimental period, ponds were drained and fish were harvested, counted, graded into four weight groups (First $=4-5$, Second $=6-8$ and Third= 9-20fish $/ \mathrm{kg}$ ) for tilapia. For mullet species fish were graded into two gradea: (grade 1:300-250 g and grade $2:<250 \mathrm{~g}$ ) and random samples of each species were taken (were caught from ponds by using fish wheels net) and frozen for proximate analysis. A triple been balance of capacity $0.1 \mathrm{~g}$ to $1600 \mathrm{~g}$ was used for weighing fish samples. Individual measurements of total length and weight of the fish samples and growth performance parameters were calculated according to the following equations:

Weight gain (WG):

Weight gain was estimated as follows;

Where:-

$$
\text { Weight gain }=\mathrm{Wt}_{1}-\mathrm{Wt}_{0}
$$

$\mathrm{Wt}_{1}=$ Mean final weight $(\mathrm{g})$

$\mathrm{Wt}_{0}=$ Mean initial weight $(\mathrm{g})$

Length gain (LG):

Length gain was estimated as follows;

Where:-

$$
\text { Length gain }=\mathrm{Lt}_{1}-\mathrm{Lt}_{0}
$$

$$
\mathrm{Lt}_{1}=\text { Mean final Length }(\mathrm{cm})
$$

$\mathrm{Lt}_{0}=$ Mean initial Length $(\mathrm{cm})$

Average daily gain ADG (g):

ADG was estimated according to Green et al. (2002) as follows;

ADG =Average weight gain (g) /Experimental period (day)

Percentage weight gain (\%):

Percentage weight gain (\%) was estimated according to Green et al. (2002).

$$
\text { = Weight gain / Mean initial fish weight } \mathrm{x} 100
$$

Specific growth rate (SGR):

Specific growth rate was estimated according toGreen et al. (2002)as follows:

$$
\operatorname{SGR}=\frac{\operatorname{Ln}^{W_{0}-\operatorname{Ln}^{\mathrm{W}}{ }_{\mathrm{t}}}}{\mathrm{T}} \times 100
$$

Where:-

$\mathrm{Ln}=$ the natural $\log$

$\mathrm{W}_{0}=$ weight (g) at the end of the experimental period.

$\mathrm{W}_{\mathrm{t}}=$ weight $(\mathrm{g})$ at the beginning of the experimental period. 


$$
\mathrm{T}=\text { period of experimental (day) }
$$

Condition factor $(\mathrm{k})$ :

Condition factor was estimated according to Hung et al. (1993) as follow:

$$
\mathrm{K}=\left(\mathrm{W} / \mathrm{L}^{3}\right) \times 100
$$

Where:-

$\mathrm{K}=$ Condition factor, coefficient of condition or

Ponderal index.

$\mathrm{W}=$ total weight of fish in grams

$\mathrm{L}=$ total length of fish in $\mathrm{cm}$.

Feed conversion ratio (FCR):

Feed conversion ratiowas estimated according to De Silva and Anderson (1995) as follow:

FCR = Dry food consumed (g) / Total weight gain (g)

Relative growth rate (RGR):

$$
\mathrm{RGR}=\frac{\text { Total weight gain }(\mathrm{g})}{\text { Initial weight }(\mathrm{g})} \times 100
$$

Gross yield of fish (GY):

Gross yield of fish was was estimated as follows:

= harvested fish weight $(\mathrm{kg}) /$ Pond.

\section{Chemical analysis of feed and body composition.}

At the beginning and the end of the experiment, 6 fish from eash speices were exposed to the chemical analysis of whole fish body. Dry matter (DM), crude protein (CP), ether extract (EE), crude fiber (CF) and ash content of diets and fish were determined according to the methods described in AOAC International. (1990): dry matter after drying in an oven at $105^{\circ} \mathrm{C}$ until constant weight; ash content by incineration in a muffle furnace at $600^{\circ} \mathrm{C}$ for $12 \mathrm{hrs}$ in a muffle Furnace; crude protein $(\mathrm{N} \times 6.25)$ by kjeldhal method after acid digestion; ether extract by petroleum ether $\left(60-80^{\circ} \mathrm{C}\right)$ extraction; fiber by drying and ashing after extraction with $0.5 \mu \mathrm{H}_{2} \mathrm{SO}_{4}$ and $0.5 \mu \mathrm{NaOH}$; nitrogen free extract (NFE) and Gross energy was calculated by differences.

\section{Partial budget analysis.}

A partial budget analysis was conducted to determine economic returns for the different tested stoken denesty (Shang, 1990). The analysis was based on farm-gate prices for harvested fish and current local market prices for all other items expressed in (LE); Egyption pound as was in season (2012).

Table 5: Farm gete prices of sold fish at harvest time.

\begin{tabular}{|c|c|c|c|c|c|c|c|}
\hline \multirow{2}{*}{ Size Grade } & \multicolumn{4}{|c|}{ Tilapia O. niloticus } & \multirow{2}{*}{ Mugil cephalus } & \multicolumn{2}{c|}{ Liza ramada } \\
\cline { 2 - 5 } \cline { 7 - 8 } & Super & $1^{\text {st }}$ & $2^{\text {nd }}$ & $3^{\text {rd }}$ & & 1 st & $2^{\text {nd }}$ \\
\hline Price(LE kg-1) & 11 & 9 & 7 & 5 & 24 & 18 & 13 \\
\hline
\end{tabular}

Market prices for production input were as follows:

Nile tilapia fingerling = LE $220 / 1000$ pieces mean weight $25 \mathrm{~g}$.

Borry fingerling = LE. $2200 / 1000$ pieces mean weight $15 \mathrm{~g}$.

Topara fingerling =LE. $750 / 1000$ pieces mean weight $10 \mathrm{~g}$.

Fish feed (25\% protein) = LE. 4100/1000 Kg-1. 


\section{Statistical analysis.}

The data were statistically analyzed of variance (ANOVA) and Duncan's Multiple-range testing to compare the mean values of the factors measured, using general linear models procedure adapted by SPSS Inc. (2008) version (16.0) statistical software package (SPSS, Inc., Chicago, Illinois, USA). The differences among treatments means were significan at $\mathrm{P}<0.05$. Statistical analysis was done according to Steel and Torrie (1980).

\section{RESULTS AND DISCUSSIONS}

\section{Effect of stocking density on growth performance of Nile tilapia}

Results of growth performance of Nile tilapia reared in poly culture system with mullet species in earthen ponds are presented in Table (6).

Table 6:Effect of stocking density on body weight gain, specific growth rate, condition factor and relative growth rate of Nile tilapia (Oreochromis niloticus) reared in polyculture system $(\mathrm{Mean} \pm \mathrm{SE})$.

\begin{tabular}{|l|l|l|l|}
\hline Treatment groups & T1 & T2 & T5 \\
\hline Initial weight (IW) & $25.00 \pm 2.9$ & $25.00 \pm 2.1$ & $25.00 \pm 2.1$ \\
Weight 8 Week & $65.00 \pm 3.3$ & $64.00 \pm 3.4$ & $64.00 \pm 4.1$ \\
Weight 16 Week & $154.50 \pm 3.4$ & $142.50 \pm 4.7$ & $148.5 \pm 3.2^{\mathrm{c}}$ \\
Final weight 24 Week (FW) & $328.5 \pm 2.80^{\mathrm{a}}$ & $314.0 \pm 2.60^{\mathrm{b}}$ & $283.5 \pm 1.5^{\mathrm{c}}$ \\
Initial length (IL) & $12.00 \pm 26$ & $12.00 \pm 3.1$ & $12.00 \pm 2.6$ \\
Final length (FL) & $30.5 \pm 0.21^{\mathrm{a}}$ & $30.5 \pm 0.58^{\mathrm{a}}$ & $28.15 \pm 0.50^{\mathrm{b}}$ \\
Total weight gain (TWG) & $303.5 \pm 3.05^{\mathrm{a}}$ & $289.0 \pm 2.70^{\mathrm{b}}$ & $258.5 \pm 0.12^{\mathrm{c}}$ \\
Daily Weight gain (DWG) & $1.68 \pm 0.20^{\mathrm{a}}$ & $1.60 \pm 0.30^{\mathrm{a}}$ & $1.35 \pm 0.12^{\mathrm{b}}$ \\
Specific growth rate (SGR)\% & $1.43 \pm 0.22^{\mathrm{a}}$ & $1.40 \pm 0.22^{\mathrm{a}}$ & $1.47 \pm 0.22^{\mathrm{a}}$ \\
Relative growth rate (RGR) & $1214.0 \pm 0.20^{\mathrm{a}}$ & $1156.0 \pm 0.13^{\mathrm{b}}$ & $1034.0 \pm 0.12^{\mathrm{c}}$ \\
Condition factor (K) & $1.15 \pm 0.14^{\mathrm{b}}$ & $1.10 \pm 0.15^{\mathrm{b}}$ & $1.27 \pm 0.22^{\mathrm{a}}$ \\
\hline
\end{tabular}

a,b,c, $\ldots$ within each raw bearing the same letters do not differ significantly $\mathrm{P}<0.05$ otherwise they do.

$\mathrm{T} 1$ = stocking density 16000 fish / feddan (12000 Nile tilapia +3000 Tobara +1000 Bouri); T2 = stocking density 19200 fish / feddan (14400 Nile tilapia +3600 Tobara +1200 Bouri) and T3 = stocking density 22400 fish / feddan (16800 Nile tilapia +4200 Tobara +1400 Bouri).

At the start of the experiment the average initial weight of Nile tilapia was 25.0g. After 8 weeks of the experimental start, averages of body weights were 65.0; 64.0 and 64.0g. For $\mathrm{T}_{1}$ (16000 tilapia and mullet/feddan); $\mathrm{T}_{2}$ (19200 tilapia + mullet/feddan) and $\mathrm{T}_{3}$ (22400 tilapia + mullet/feddan), respectively, and differences among the tested stocking density at this period in body weight of tilapia were insignificant. At 16 weeks after the start of the experiment, averages of Nile tilapia body weights were $154.5 ; 142.5$ and $148.5 \mathrm{~g}$ for $\mathrm{T}_{1} ; \mathrm{T}_{2}$ and $\mathrm{T}_{3}$, respectively. The analysis of variance for body weight during this period show that differences among the stocking densities were significant $(\mathrm{P}<0.05)$ where the lowest stocking density showed significantly $(\mathrm{P}<0.05)$ the highest body weights followed in a significant $(\mathrm{P}<0.05)$ decreasing order by $\mathrm{T}_{3}$ and $\mathrm{T}_{2}$, respectively. The fluctuations in body weight during this period may due to the fact that the living space in ponds was still not an effective factor to have effect on body weight, thus the fish weights during this period were still low. As presented in the same Table, averages of final weights at the end of the experimental period for $T_{1}, T_{2}$ and $T_{3}$ were 328.5, 314.0 and 283.5g respectively and $\mathrm{T}_{1}$ showed significantly $(\mathrm{P}<0.05)$ the highest final weights followed in a significant $(\mathrm{P}<0.05)$ decreasing order by $\mathrm{T}_{2}$ and $\mathrm{T}_{3}$, respectively. These results indicate that the final weights of Nile tilapia decreased significantly with each increase in the stocking density. Concerning body length (BL), results of Table (6), 
show that the initial length of Nile tilapia at the start of the experiment was $12.0 \mathrm{~cm}$. At the end of the experimental period, averages of body length of Nile tilapia (24 weeks after start) were found to be $30.5 ; 30.5$ and $28.15 \mathrm{~cm}$ for $\mathrm{T}_{1}, \mathrm{~T}_{2}$ and $\mathrm{T}_{3}$, respectively. The statistical evaluation of the results showed that both $T_{1}$ and $T_{2}$ had significantly $(\mathrm{P}<0.05)$ longer bodies at end of the experimental period compared to $\mathrm{T}_{3}$ and differences in this trait among $T_{1}$ and $T_{2}$ were insignificant. As presented in Table (6), averages of total weight gain (WG) of Nile tilapia as affected with stocking density for $\mathrm{T}_{1} ; \mathrm{T}_{2}$ and $\mathrm{T}_{3}$ were found to be 303.5; 289.0 and 258.5g., respectively and the $\mathrm{T}_{1}$ showed significantly $(\mathrm{P}<0.05)$ the highest $\mathrm{WG}$ followed in significance $(\mathrm{P}<0.05)$ decreasing order by $\mathrm{T}_{2}$ and $\mathrm{T}_{3}$, respectively. Furthermore, results of the same Table show that both $\mathrm{T}_{1}$ and $\mathrm{T}_{2}$ showed significantly $(\mathrm{P}<0.05)$ higher averages of daily gain compared to $T_{3}$. Results of Table (6) show that averages of specific growth ranged between $1.40 \%\left(\mathrm{~T}_{2}\right)$ and $1.47 \%\left(\mathrm{~T}_{3}\right)$ and differences among the experimental groups were insignificant. Averages of relative growth rate for $T_{1} ; T_{2}$ and $T_{3}$ were 1214.0, 1156.0 and 1034.0 respectively and the statistical analysis show that the highest RGR $(\mathrm{P}<0.05)$ records were obtained by $\mathrm{T}_{2}$ and followed in a significant decreasing order by $T_{2}$ and $T_{3}$, respectively (Table 6 ). As presented in the same Table $\mathrm{T}_{3}$ recorded significantly $(\mathrm{P}<0.05)$ the highest condition factor compared with $\mathrm{T}_{1}$ and $\mathrm{T}_{2}$ indicating that $\mathrm{T}_{3}$ grow more in weight than in length. These results are in accordance with the findings of Wohlfarth et al. (1985) who reported that growth performance and survival of tilapia were influenced by their stocking rate, the species of fish co-stocked with them and feeding regimes. Also results of the present study are in agreement with the findings of Abou Zied et al. (2005), who reported that at harvest, tilapia body weight, total and daily gain, and specific growth rate were significantly affected with stocking density of tilapia and mallet where the highest values were recorded by stocking density of 7700 fish/feddan (10 tilapia: 1 mullet) followed by the stocking density 8000 fish/feddan (3 tilapia: 1 mullet), 6000 fish/feddan (5 tilapia: 1 mullet) and 11000 fish/feddan (10 tilapia: 1 mullet), respectively. Results of the present study are also in accordance with the findings of Danaher et al. (2007) who reported that the average harvest weight of tilapia stocked at low density in poly culture system was significantly higher than that stocked at high density in poly culture system. Furthermore Florence and Harrison (2012) studied the effect of stocking ratios $1: 1 ; 1: 2$ and 1:3 Clarkias gariepinus African catfish Oreochromis niloticus (Nile Tilapia) respectively at $10 \mathrm{fish} / \mathrm{m}^{2}$ reared in concrete tanks for twelve weeks on growth performance survival rate of both tested species. The authors reported that the highest stocking density produced the highest (157.85g.) mean weight gain for the catfish. Mean weight gain for Nile tilapia in the same tank took the reverse order. They added that specific growth data recorded for the catfish. Revealed an intermediate value at the highest (4.25\%) and lowest (4.32\%) stocking densities, while the highest was recorded at the intermediates stocking density (4.41). results of Table (6) are also in agreement with the findings of Hemat Mohmoud (2012) who studied the effect of stoking density of Nile tilapia (102 fish/m $\mathrm{m}^{3}$ and 204 fish $/ \mathrm{m}^{3}$ ) with an initial weight of $7 \mathrm{~g}$. on growth performance for 14 weeks. She reported that live body weight; daily weight gain and specific growth rate of Nile tilapia were significantly decreased with increasing stocking density during most of the experimental periods studied.

Effect of stocking density on growth performance of gray mullet (Bouri).

Results of growth performance of grey mullet including final weight (FW), final length (FL), weight gain (WG); daily weight gain (DWG), specific growth rate (SGR), relative growth rate (RGR) and condition factor (K) as affected with stoking 
density in poly culture system with Nile tilapia and Liza ramada are presented in Table (7).

Table 7: Effect of stocking density on body weight gain, specific growth rate, condition factor and relative growth rate of Gray mullet (M. cephalus)reared in polyculture system (mean \pm SE).

\begin{tabular}{|l|l|l|l|}
\hline Treatment groups & T1 & T2 & T3 \\
\hline Initial weight (IW) & $15.00 \pm 2.1$ & $15.00 \pm 1.1$ & $15.00 \pm 1.6$ \\
Weight 8 Week & $39.50 \pm 3.2$ & $43.00 \pm 2.1$ & $47.00 \pm 2.5$ \\
Weight 16 Week & $155.0 \pm 3.3$ & $133.5 \pm 2,4$ & $120.5 \pm 3.6$ \\
Final weight 24 Week (FW) & $312.0 \pm 2.84^{\mathrm{a}}$ & $285.0 \pm 2.67^{\mathrm{b}}$ & $235.0 \pm 1.12^{\mathrm{c}}$ \\
Initial length (IL) & $8.000 \pm 1.2$ & $8.000 \pm 1.3$ & $8.000 \pm 1.3$ \\
Final length (FL) & $31.15 \pm 0.38^{\mathrm{a}}$ & $30.25 \pm 0.41^{\mathrm{b}}$ & $28.35 \pm 0.35^{\mathrm{c}}$ \\
Total weight gain (TWG) & $297.0 \pm 3.11^{\mathrm{a}}$ & $270.0 \pm 2.61^{\mathrm{b}}$ & $220.0 \pm 2.42^{\mathrm{c}}$ \\
Daily Weight gain (DWG) & $1.65 \pm 0.40^{\mathrm{a}}$ & $1.500 \pm 0.51^{\mathrm{b}}$ & $1.35 \pm 0.42^{\mathrm{c}}$ \\
Specific growth rate (SGR)\% & $1.86 \pm 0.42^{\mathrm{a}}$ & $1.630 \pm 0.52^{\mathrm{b}}$ & $1.52 \pm 0.32^{\mathrm{c}}$ \\
Relative growth rate (RGR) & $1980 . \pm 0.40^{\mathrm{a}}$ & $1800.0 \pm 0.33^{\mathrm{b}}$ & $1466.0 \pm 0.32^{\mathrm{c}}$ \\
Condition factor (K) & $1.02 \pm 0.14^{\mathrm{a}}$ & $1.020 \pm 0.15^{\mathrm{a}}$ & $1.03 \pm 0.15^{\mathrm{a}}$ \\
\hline
\end{tabular}

a, b, c, ... within each raw bearing the same letters do not differ significantly $\mathrm{P}<0.05$ other wise the do.

T1 = stocking density 16000 fish / feddan

(12000 Nile tilapia +3000 Tobara +1000 Bouri) $;$ T2 = stocking density 19200 fish / feddan ( 14400 Nile tilapia +3600 Tobara +1200 Bouri) and T3 = stocking density 22400 fish / feddan ( 16800 Nile tilapia + 4200 Tobara + 1400 Bouri)

As presented in this Table average of initial weight $(\mathrm{g})$ and length $(\mathrm{cm})$ of gray mullet were $15.0 \mathrm{~g}$. and $8.0 \mathrm{~cm}$, respectively. After 8 weeks of the experimental start, it ranged between 39.5 and $47.0 \mathrm{~g}$ with insignificant differences among the tested stoking densities, which indicate that the stocking density released no significant effects during this period due to the low size of fish and the sufficient living space. After 16 weeks of the experimental start, averages of body weights of gray mullet for $\mathrm{T}_{1} ; \mathrm{T}_{2}$ and $\mathrm{T}_{3}$ were found to be $155.0 ; 133.5$ and $120.5 \mathrm{~g}$, respectively and the statistical evaluation for final weight indicate that FW decreased significantly $(\mathrm{P}<0.05)$ with each increase in the fish stocking density. There results indicate that as the fish grow in size and weight the effect of stoking density became more pronounced on body weight of grey mullet. The same trend was observed with FL where FL of grey mullet decreased significantly $(\mathrm{P}<0.05)$ with each increase in fish stocking density. As presented in Table (7) averages of WG decreased significantly from 297.0 to 270.0 and $220.0 \mathrm{~g}$. for $\mathrm{T}_{1} ; \mathrm{T}_{2}$ and $\mathrm{T}_{3}$, respectively. The same tread was observed with DWG and SGR where both records for grey mullet decreased significantly $(\mathrm{P}<0.05)$ with each increase in the stocking density of the tested fish species. Averages of RGR for gray mullet of $T_{1} ; T_{2}$ and $T_{3}$ were 1980; 1800 and 1460 , respectively and the analysis of variance for this trait indicate that RGR of grey mullet decreased significantly with each increase in the stocking density. The RGR values of $\mathrm{T}_{2}$ and $\mathrm{T}_{3}$ as percentage of $\mathrm{T}_{1}(200 \%)$ were 90.9 and $74 \%$, respectively which may show clearly that at the highest stocking density the RGR of grey mullet decreased by more than $25 \%$ compared to $T_{1}$. As presented in Table (7) averages of condition factor ranged between 1.02 for $T_{1}$ and $T_{2}$ and 1.03 for $T_{3}$ and differences in this trait among the tested stocking densities were insignificant. Results of growth performance parameters of grey mullet stocked in poly culture system with Nile tilapia and Liza ramada indicate in general that all growth parameters except condition factor decreased significantly with each increase in the stoking densities tested. These are in agreement with the findings of Abou Zied et al. (2005) who stocked Nile tilapia and grey mullet at densities of 6000; 7700; 8000 and 11000 fish/feddan and reported that the harvesting body weight, total gain, daily gain and specific growth rate were 
significantly affected with stocking density of both species when the highest values were recorded by the density of 7700 fish/feddan followed by the density of 8000 fish/feddan, 6000 fish/feddan and 11000 fish/feddan, respectively. Results of the present study are also in partial agreement with the findings of Abou Zied and Hassouna (2007) who culture Nile tilapia and mullet (15000 tilapia+750 mullet/feddant) with 0.0 or 150 or 300 meager/feddan for 180 days in earthen ponds and found that mullet showed significant improvement in weight when meager was stocked at a rate of 300 fingerlings/feddan. In this connection Milstein and Svirsky (1996) reported that the available resources efficiently, Maximize the synergistic fishfish and fish environment relationships and minimize the antagonistic ones.

\section{Effect of stocking density on growth performance of Tobara mullet (Liza ramada) (TM)}

At the experimental start average initial weight of Tobara for all treatments was $10 \mathrm{~g}$. After 6 weeks of start averages of body weight of TM were 32.5; 33.0 and $32.0 \mathrm{~g}$ (Table 8) for $\mathrm{T}_{1} ; \mathrm{T}_{2}$ and with insignificant differences among the tested stocking $\mathrm{T}_{3}$, respectively densities.

Table 8: Effect of stocking density on body weight gain, specific growth rate, condition factor and relative growth rate of Tobara mullet (Liza ramada) reared in polyculture system (mean $\pm \mathrm{SE}$ ).

\begin{tabular}{|c|c|c|c|}
\hline Treatment groups & $\mathrm{T} 1$ & $\mathrm{~T} 2$ & T3 \\
\hline Initial weight (IW) & $10.0 \pm 1.4$ & $10.0 \pm 1.2$ & $10.0 \pm 1.3$ \\
\hline Weight 8 Week & $32.5 \pm 1.7$ & $33.0 \pm 2,3$ & $32.0 \pm 3.4$ \\
\hline Weight 16 Week & 160.01 .3 & $142.5 \pm 3.1$ & $134.0 \pm 2.7$ \\
\hline Final weight 24 Week (FW) & $296.5 \pm 2.14^{\mathrm{a}}$ & $263.0 \pm 2.57^{\mathrm{b}}$ & $213.5 \pm 1.52^{\mathrm{c}}$ \\
\hline Initial length $\quad$ (IL) & $6.5 \pm 1.1$ & $6.5 \pm 1.2$ & $6.5 \pm 1.4$ \\
\hline Final length $\quad$ (FL) & $30.40 \pm 0.38^{\mathrm{a}}$ & $28.10 \pm 0.31^{\mathrm{b}}$ & $25.50 \pm 0.35^{\mathrm{c}}$ \\
\hline Total weight gain (TWG) & $286.5 \pm 3.21^{\mathrm{a}}$ & $253.0 \pm 2.51^{\mathrm{b}}$ & $203.5 \pm 0.42^{\mathrm{c}}$ \\
\hline Daily Weight gain $\quad$ (DWG) & $1.59 \pm 0.40^{\mathrm{a}}$ & $1.40 \pm 0.45^{\mathrm{b}}$ & $1.35 \pm 0.42^{\mathrm{C}}$ \\
\hline Specific growth rate (SGR)\% & $1.82 \pm 0.22^{\mathrm{a}}$ & $1.81 \pm 0.22^{\mathrm{a}}$ & $1.70 \pm 0.32^{\mathrm{b}}$ \\
\hline Relative growth rate (RGR) & $2865.0 \pm 0.20^{\mathrm{a}}$ & $2530.0 \pm 0.04^{b}$ & $2035.0 \pm 0.03^{c}$ \\
\hline Condition factor $\quad(\mathrm{K})$ & $1.05 \pm 0.24^{\mathrm{C}}$ & $1.18 \pm 0.25^{b}$ & $1.28 \pm 4.22^{\mathrm{a}}$ \\
\hline
\end{tabular}

a, b, c ... within each raw bearing the same letters do not differ significantly $\mathrm{P}<0.05$ other wise the do.

$\mathrm{T} 1=$ stocking density 16000 fish / feddan $(12000$ Nile tilapia +3000 Tobara +1000 Bouri $) ; \mathrm{T} 2=$ stocking density 19200 fish / feddan ( 14400 Nile tilapia +3600 Tobara +1200 Bouri) and T3 = stocking density 22400 fish / feddan ( 16800 Nile tilapia + 4200 Tobara +1400 Bouri).

As presented in the same Table averages of body weight of (TM) after 16 weeks of the experimental start were $160.0 ; 142.5$ and $134.0 \mathrm{~g}$ for $\mathrm{T}_{1} ; \mathrm{T}_{2}$ and $\mathrm{T}_{3}$, respectively and the statistical evaluation for body weight indicate that body weight of (TM) decreased significantly $(\mathrm{P}<0.05)$ with each increase in the stocking density.

As presented in Table (8) results revealed that the final weight after 24 weeks of the experimental start decreased almost significantly in a linear manner from 296.5 to 263.0 and $213.5 \mathrm{~g}$ in $\mathrm{T}_{1} ; \mathrm{T}_{2}$ and $\mathrm{T}_{3}$, respectively. The same trend was observed with final length where this trait decreased significantly $(\mathrm{P}<0.05)$ with each increase in the stocking density tested.

Results of Table (8) show that weight gain, daily weight gain and relative growth rate of (TM) decreased significantly with each increase in the stocking density Furthermore, specific growth rate of $\mathrm{T}_{1}$ and $\mathrm{T}_{2}$ was significantly $(\mathrm{P}<0.05)$ higher than $\mathrm{T}_{3}$. As presented in the same Table condition factor showed significant increase with each increase in the stocking density. In general condition factor reflects through its variations information on the physiological state of the fish in relation to its welfare. The increase incondition factors with each increase in the stocking density indicate that at higher density the fish gain more in weight than in length. These results are in 
accordance with the findings of (Abou Zied et al., 2005); Abou Zied and Hassouna (2007). They also are in partial agreement with the findings of Aksungur et al., (2007) who studied the effect of stocking density of Turbot (30,60,90 and 120 fish $\mathrm{m}^{2}$ ) reared in sea cages for 206 days and found that the mean final weight of the fish stocked at densities of $30 ; 60,90$ and $120 \mathrm{~m}^{2}$ reached 178.3; 182.7; 196.1 and $164.6 \mathrm{~g}$, respectively. They added that growth rate was fast up to $90 \mathrm{fish} / \mathrm{m}^{2}$ and dropped after that.

In general results of Tables $(6,7,8)$ show clearly that the effect of stocking density of the three tested fish species released no significant effects on fish body weight after eight weeks of experimental start, this the body weights were still low and the living space in ponds was quite suitable for growth and biological activities of fish. The stocking density started to release effects on final weights after 16 weeks of the experimental start and the effect continued till the end of the experimental period where fish weight decreased with increasing the stocking density. These results are in agreement with the findings of Moustafa (1993) who reported that increasing the stocking density of tilapia reared in cages constructed in earthen ponds decreased significantly the final weight of the fish. FurthermoreCoche (1976) reported that the growth rate of fish decreased with increasing stock density but the production increased in the cage up to an initial stocking density of 36 to $50 \mathrm{~kg} . / \mathrm{m}^{3}$. The same author added that the apparent drop in productivity above this range could suggest some of social interaction, due to crowding that affecting growth. In this connection, Chen and Prowse (1964) showed that there are affects of the free movement of fish in a body of water on their growth rate. They called this the living space effect. On the other hand, Swingle (1956) working with gold fish, with buffalo fish as common carp and certain other fishes, suggested that what he called a "space factor" was not necessarily responsible for limiting production and reproduction at higher densities, but that this effect was mainly due to the presence of a hormone like secretion or excretion that acted as a repressive factor. This effect however is different from that described by Chen and Prowse (1964) for the malacca all-tilapia hybrid when fish were kept either in small divided off section of a pond or in separate small ponds, where much smaller ones than those fish in larger bodies of water. They attributed the difference in growth to be a result of aggression and intraocular dominance within groups as well as intra circular dominance between groups.

\section{Effect of stocking density on final biomass, feed intake and feed conversion ratio} (FCR) of the tested species.

As presented in Table (9), averages of initial stocked biomass from Nile tilapia and mallet species for $\mathrm{T}_{1}, \mathrm{~T}_{2}$ and $\mathrm{T}_{3}$ were $345 ; 414$ and $483 \mathrm{~kg}$., respectively and the final biomass after 24 weeks of experimental period were 5143.5; 5810.4 and 5971.7 $\mathrm{kg}$ for the same treatment groups cited above, respectively. These results indicate in general that the average initial biomass as well as the final biomass increased with each increase in the stocking density and reached its maximum in $T_{3}$ where 22400 fish were stocked per feddan.

As presented in the same Table averages of gain in biomass for $T_{1} ; T_{2}$ and $T_{3}$ were found to be $4798.5 ; 5396.4$ and $5488.7 \mathrm{~kg}$, respectively. These results indicate that the gain in biomass increased almost in a linear manner with each increase in fish stocking density. The same trend was observed with feed intake were the averages of feed intake during the whole experimental period increased from 8333.0; to 9786.5 and to $11102.0 \mathrm{~kg}$ for $\mathrm{T}_{1} ; \mathrm{T}_{2}$ and $\mathrm{T}_{3}$, respectively. As presented in Table (9), averages of FCR (calculated as kg. feed required for each kg. gain in weight were found to be $1.73 ; 1.81$ and $2.02 \mathrm{~kg}$ feed $/ \mathrm{kg}$. gain in weight for $\mathrm{T}_{1} ; \mathrm{T}_{2}$ and $\mathrm{T}_{3}$, respectively. 
Table 9: Effect of stocking density on feed conversion ratio of the species tested.

\begin{tabular}{|l|l|l|l|}
\hline Treatments & $\mathrm{T} 1$ & $\mathrm{~T} 2$ & $\mathrm{~T} 3$ \\
\hline Initial biomass, kg & 345.0 & 414.0 & 483.0 \\
Final biomass, kg & 5143.5 & 5810.4 & 5971.7 \\
Gain in biomass,kg & 4798.5 & 5396.4 & 5488.7 \\
feed intake, kg & 8333.0 & 9786.5 & 11102.0 \\
FCR & 1.73 & 1.81 & 2.02 \\
\hline
\end{tabular}

$\mathrm{T} 1$ = stocking density 16000 fish / feddan (12000 Nile tilapia + 3000 Tobara + 1000 Bouri); T2 = stocking density19200 fish / feddan (14400 Nile tilapia +3600 Tobara +1200 Bouri) and T3 = stocking density 22400 fish $/$ feddan $(16800$ Nile tilapia +4200 Tobara + 1400 Bouri).

These results indicate that FCR increased (worth) with each increase in the stocking density. These results may indicate that of lower stoking density more live food was available to be consumed than in higher stocking densities where the fish were more dependable on the artificial diet which increased the FCR. These results are in partial agreement with the findings of Ammar (2009) who found that stocking of Nile tilapia (0.3g initial weight) at densities of 30; 40 and 50 thousand fish/feddan resulted in FCR values of 1.8; 1.8 and 1.9, respectively indicating that a stocking density are 40 thousand fish/feddan tensed to increase FCR. The same author reported also that the highest fish production (total biomass) per feddan increased with each increase in the fish stocking density. Results of Table (9) are also in accordance with the findings of Abdel-Hakim et al. (2001); Abdel-Hakim and Ammar (2005); Abdelhakim and Salah (2008). Results of the present study are also in partial agreement with the findings of El-Dahhar et al. (2006) who reported that the best FCR values of Nile tilapia and striped mullet was obtaine in polyculture system when 3 mullet were stocked with 7 tilapia/ $\mathrm{m}^{3}$ compared to ratios of $5: 5$ or 7:3 mullet to tilapia. In this connection, Aksungur et al.(2007) tested the effect of stocking density of turbot (Psetta maxima) reared in sea cages at densities of 30; 60; 90 and 120 fish $\mathrm{m}^{3}$.They reported that FCR values were estimated as 1.95; 1.85; 2.09 and 1.88 for the stocking densities cited above, respectively. The same authors added that stocking density of turbot had no significant effects on FCR. In this connection El naggar et al. (2008) tested growth performance of Nile tilapia stocked in polyculture system with African catfish and silver carp (85\% tilapia, 15\% catfish and 300 specimen silver carp) at densities 3 or $5 \mathrm{fish} / \mathrm{m}^{3}$. They reported that the best (lowest) FCR was achieved with the stocking density $3 \mathrm{fish} / \mathrm{m}^{3}$ with chemical fertilizers followed in an increasing order by $3 \mathrm{fish} / \mathrm{m}^{3}$ with organic fertilizer, $5 \mathrm{fish} / \mathrm{m}^{3}$ with chemical fertilizer and $5 \mathrm{fish} / \mathrm{m}^{3}$ with organic fertilizers, respectively.

\section{Whole body chemical composition:}

Concerning Nile tilapia, results of whole body composition including dry matter (DM); crude protein (CP); ether extract (EE) and grass energy (GE) are presented in Table (10).

As presented in this Table averages of dry matter contents in whole tilapia bodies for $T_{1} ; T_{2}$ and $T_{3}$ were 28.53; 27.49 and 30.57 percent, respectively and $T_{3}$ showed significantly $(\mathrm{P}<0.05)$ the highest $\mathrm{DM}$ contents followed in a decreasing order $(\mathrm{P}<0.05)$ by $\mathrm{T}_{1}$ and $\mathrm{T}_{2}$, respectively. These results are in partial agreement with the finding of Abdel-Hakim et al. (2013) who reported that DM contents in whole tilapia bodies ranged between 30.65 and 27.29\%. Regarding the CP contents in tilapia whole bodies results of Table (10) indicate that CP contents of $\mathrm{T}_{1} ; \mathrm{T}_{2}$ and $\mathrm{T} 3$ were 64.20 and 64.85 and $65.40 \%$, respectively and $\mathrm{T}_{3}$ showed significantly $(\mathrm{P}<0.05)$ higher $\mathrm{CP}$ contents in the DM compared to $\mathrm{T}_{2}$ and $\mathrm{T}_{1}$.

In this respect, Abdel-Hakim et al. (2013), reported that CP contents in tilapia whole bodies ranged between 61.81 and $65.40 \%$ and significantly affected with type 
of fertilizer and feeding. Furthermore averages of EE contents ranged between 19.65 and $19.83 \%$ with insignificant differences among treatments. In this respect AbdelHakim et al. (2013), reported that EE contents in whole tilapia bodies ranged between 17.50 and $19.84 \%$ and was significantly affected by feeding and manuring type.

Table 10: Effect of stocking density on chemical composition of the whole body of Nile tilapia (O. niloticus), Gray mullet (M. cephalus) and Liza ramada (L. ramada) reared in polyculture system.

\begin{tabular}{|c|c|c|c|c|c|c|c|}
\hline Item & Treat. & Dry matter & Protein & Ether extract & Ash & *NFE & **GE Kcal/100g \\
\hline \multicolumn{2}{|l|}{ Initial } & $27.36 \pm 0.51$ & $62.80 \pm 0.50$ & $18.00 \pm 0.51$ & $12.70 \pm 0.54$ & $6.50 \pm 0.51$ & $548.25 \pm 1.54$ \\
\hline \multirow{3}{*}{$\begin{array}{l}\text { Final } \\
\text { Nile tilapia (O. niloticus) }\end{array}$} & $\mathrm{T} 1$ & $28.53 \pm 0.86^{b}$ & $64.20 \pm 0.80^{\mathrm{bc}}$ & $19.65 \pm 0.67^{b}$ & $13.34 \pm 0.48^{\mathrm{ab}}$ & $2.76 \pm 0.46^{\mathrm{a}}$ & $556.51 \pm 1.30^{\mathrm{b}}$ \\
\hline & $\mathrm{T} 2$ & $27.49 \pm 0.50^{c}$ & $64.85 \pm 0.50^{\mathrm{b}}$ & $19.66 \pm 0.68^{\mathrm{b}}$ & $13.16 \pm 0.48^{\mathrm{ab}}$ & $1.88 \pm 0.45^{\mathrm{b}}$ & $556.54 \pm 1.22^{\mathrm{b}}$ \\
\hline & T3 & $30.57 \pm 0.68^{\mathrm{a}}$ & $65.40 \pm 0.50^{\mathrm{a}}$ & $19.83 \pm 0.68^{\mathrm{a}}$ & $13.67 \pm 0.68^{\mathrm{a}}$ & $1.10 \pm 0.45^{\mathrm{c}}$ & $557.94 \pm 2.60^{\mathrm{a}}$ \\
\hline \multicolumn{2}{|l|}{ Initial } & $29.50 \pm 0.51$ & $57.62 \pm 0.50$ & $27.99 \pm 0.50$ & $12.82 \pm 0.51$ & $1.57 \pm 0.50$ & $593.32 \pm 1.50$ \\
\hline \multirow{3}{*}{$\begin{array}{l}\text { Final Gray mullet (Mugih } \\
\text { sephalus) }\end{array}$} & T1 & $27.84 \pm 0.31^{\mathrm{c}}$ & $56.55 \pm 0.43^{b}$ & $30.68 \pm 0.58^{\mathrm{a}}$ & $11.32 \pm 0.41^{\mathrm{ab}}$ & $1.40 \pm 0.42^{\mathrm{b}}$ & $612.12 \pm 2.52^{\mathrm{a}}$ \\
\hline & $\mathrm{T} 2$ & $29.85 \pm 0.34^{b}$ & $60.53 \pm 0.51^{\mathrm{a}}$ & $26.73 \pm 0.57^{\mathrm{c}}$ & $11.65 \pm 0.42^{\mathrm{a}}$ & $1.26 \pm 0.31^{\mathrm{bc}}$ & $596.49 \pm 1.53^{\mathrm{c}}$ \\
\hline & T3 & $30.32 \pm 0.44^{\mathrm{a}}$ & $55.80 \pm 0.53^{c}$ & $29.64 \pm 0.57^{\mathrm{b}}$ & $10.85 \pm 0.50^{c}$ & $2.69 \pm 0.50^{\mathrm{a}}$ & $603.27 \pm 0.57^{\mathrm{b}}$ \\
\hline \multicolumn{2}{|l|}{ Initial } & $30.36 \pm 0.05$ & $56.37 \pm 0.04$ & $19.97 \pm 0.05$ & $14.74 \pm 0.04$ & $8.92 \pm 0.05$ & $540.75 \pm 1.03$ \\
\hline \multirow{3}{*}{$\begin{array}{l}\text { Final Liza ramada } \\
\text { (Liza ramada) }\end{array}$} & $\mathrm{T} 1$ & $29.79 \pm 0.50^{b}$ & $53.06 \pm 0.48^{\mathrm{C}}$ & $24.78 \pm 0.37^{\mathrm{a}}$ & $15.32 \pm 0.55^{\mathrm{bc}}$ & $6.81 \pm 0.50 a$ & $559.05 \pm 1.50^{\mathrm{a}}$ \\
\hline & $\mathrm{T} 2$ & $29.82 \pm 0.52^{\mathrm{b}}$ & $56.32 \pm 0.48^{\mathrm{b}}$ & $21.73 \pm 0.48^{\mathrm{b}}$ & $15.82 \pm 0.52^{\mathrm{b}}$ & $6.12 \pm 0.53 b$ & $545.58 \pm 1.30^{b}$ \\
\hline & T3 & $33.03 \pm 0.48^{\mathrm{a}}$ & $58.25 \pm 0.47^{\mathrm{a}}$ & $20.36 \pm 0.50^{c}$ & $16.56 \pm 0.51^{\mathrm{a}}$ & $4.81 \pm 0.52 \mathrm{c}$ & $538.24 \pm 1.70^{c}$ \\
\hline
\end{tabular}

T1 = stocking density 16000 fish / feddan (12000 Nile tilapia + 3000 Tobara + 1000 Bouri) ; T2 = stocking density 19200 fish / feddan (14400 Nile tilapia + 3600 Tobara +1200 Bouri) and T3 = stocking density 22400 fish / feddan( 16800 Nile tilapia +4200 Tobara +1400 Bouri).

a,b,c ... within each raw bearing the same letters do not differ significantly $\mathrm{P}<0.05$ otherwise the do.

* Nitrogen Free Extract calculated as: 100- \% ( Protein + Lipid + Ash + Crude fiber).

${ }^{* *} \mathrm{GE}$ (gross energy) calculated using the values 4.1, 5.6 and 9.44 Kcal GE/g DM of carbohydrate, protein and fat, respectively.

As presented in Table (10) ash contents in the DM of whole Nile tilapia bodies ranged between 13.16 and $13.67 \%$ and differences among stocking densities were insignificant. In this contents Abdel-Hakim et al. (2013) reported higher values of ash contents in whole bodies of Nile tilapia which ranged between 10.36 and $11.74 \%$ and the ash values were significantly affected with type of fertilization with feeding. As presented in Table (10) averages of NFE contents in the DM of Nile tilapia whole bodies for $\mathrm{T}_{1} ; \mathrm{T}_{2}$ and $\mathrm{T}_{3}$ were $2.76 ; 1.88$ and $1.10 \%$, respectively and the statistical evaluation of NFE indicate that $\mathrm{T}_{1}$ had significantly $(\mathrm{P}<0.05)$ the highest NFE records and followed in a significant $(\mathrm{P}<0.05)$ decreasing order by $\mathrm{T}_{2}$ and $\mathrm{T}_{3}$, respectively. The results concerning NFE contents in Nile tilapia whole bodies (Table 10) were lower than that reported by El-Kotamy (2008) who showed that NFE contents in whole tilapia bodies ranged between 15.12 and 20.58\%. Also Abdel-Hakim et al. (2013) reported that NFE contents in whole tilapia bodies ranged between 3.02 and 9.41\% and was affected by type of fertilization and feeding. As presented in the same Table averages of GE contents in the DM of tilapia whole bodies ranged between 556.51 and $557.94 \mathrm{kcal} / 100 \mathrm{gm}$ and differences in this trait among the stocking densities tested were insignificant. In this respect Hassouna et al. (1998) reported that energy contents (Kcal/gm.) in whole Nile tilapia bodies were 5.57; 5.60 and 5.56 kcal./gm. In fish reared in ponds fertilized only with chicken litter + urea + super phosphate; ponds received artificial feeds only and ponds received fertilization + artificial feed, respectively. Also Abdel-Hakim et al. (2013) reported that $\mathrm{GE} / \mathrm{kcal} / 100 \mathrm{~g}$ contents in whole Nile tilapia bodies ranged between 549.91 and $568.85 \mathrm{kcal} / 100 \mathrm{~g}$. which almost in accordance with the results of present study. Concerning whole body composition of Gray results of Table (10) revealed that initial contents of DM, CP, EE, and, NFE and GF were found to be 29.00, 27.00, 13.0, 2.95 on the DM basis and $543.52 \mathrm{kcal} / 100 \mathrm{~g}$., respectively. At the eud of the experimental period T3 recorded significantly $(\mathrm{P}<0.05)$ the highest DM contents followed in a significantly $(\mathrm{P}<0.05)$ decreasing order by $\mathrm{T} 2$ and $\mathrm{T} 1$ respectively. On the other hand 
T2 recorded the highest $(\mathrm{P}<0.05) \mathrm{CP}$ contents followed in a significantly $(\mathrm{P}<0.05)$ decreasing order by $\mathrm{T} 1$ and $\mathrm{T} 3$ respectively. Furthermore both $\mathrm{T} 1$ and $\mathrm{T} 3$ groups recorded higher EE $(\mathrm{P}<0.05)$ compared to $\mathrm{T} 2$.As presented in the same Table T3 recorded higher ash contents compared to $\mathrm{T} 1$ and T3. Concerning NFE contents group T3 recorded the highest value followed by T2 and T3 $(\mathrm{P}<0.05)$ respectively. Results of Table (10) revealed that T1 recorded contents the highest GE contents $(\mathrm{P}<0.05)$ followed in a significant decreasing order by T1 and T3 respectively. Concerning whole body composition of Tobara (Liza ramada), results of Table (10) reveal that DM; CP; EE; ash; NFE\% and GE/Kcal/1000g were 30; 60; 55.37; 20.97;15.00;8.66\% and $543 \mathrm{kcal} / 100 \mathrm{~g}$, respectively. At termination of the experimental period T3 recorded higher EE $(\mathrm{P}<0.05) \mathrm{DM}$ and $\mathrm{CP}$ contents compared to the other groups, while T1 recorded the highest $(\mathrm{P}<0.05) \mathrm{EE}$; NFE and GE contents compared to T2 and T3. Furthermore T3 recorded the highest $(\mathrm{P}<0.05)$ ash contents in the whole body which reflected on the Lowes GE contents in this group .In this context, Abdel-Hakim et al.,(2013) reported that the DM , CP , EE , ash, NFE\% and GE / kcal/100 in the DM of Gray mullet (Bouri) whole bodies ranged between 27.45 to 31.66; 55.80 to 60.49 ;26.70 to30.69; $11.84 ; 1.18$ to $1.77 \%$ and 595.6 to $612.12 \mathrm{kcal} / 1000 \mathrm{~g}$, respectively. For Tobara (Liza ramada) the same authors reported that DM contents in whole fish body ranged between 28.5, to 33.00,\%; CP \% between 53.07 and $58.21 \%$; ash between 15.13 to $16.57 \%$; NFE 4.87 and $7.19 \%$ and GE 538.03 and 559.19 kcal/1000 g. Results of Abdel-Hakim et at (2013) for Gray mullet (Bouri) and Liza ramada are in partial agreement with the findings presents in Table (10).

Effect of stocking density on pond water quality.

Averages of physico-chemical characteristics during the whole experimental period are presented in Table (11).

Table 11: Average physical-chemical characteristics of water ponds.

\begin{tabular}{|l|l|l|l|}
\hline Treatments & T1 & T2 & T3 \\
\hline Water temperature $\left(\mathrm{C}^{0}\right)$ & 25.46 & 25.54 & 25.71 \\
Dissolved oxygen $(\mathrm{mg} / \mathrm{L})$ & 6.97 & 6.68 & 6.03 \\
pH value degrees & 7.20 & 7.35 & 8.10 \\
Total ammonia(NH$\left./ \mathrm{NH}_{3}\right) \mathrm{mg} / \mathrm{l}$ & 0.25 & 0.35 & 0.43 \\
Nitrate $\left(\mathrm{NO}_{3}-\mathrm{N}\right) \mathrm{mg} / \mathrm{l}$ & 0.22 & 0.24 & 0.34 \\
Nitrite $\left(\mathrm{NO}_{2}-\mathrm{N}\right) \mathrm{mg} / \mathrm{l}$ & 0.26 & 0.32 & 0.35 \\
Salinity $(\mathrm{g} / \mathrm{l})$ & 2.32 & 2.32 & 2.34 \\
\hline
\end{tabular}

Results is this Table reveal that water temperature ranged between 25.46 to 25.71c0 dissolved oxygen between 6.03 and $6.97 \mathrm{mg} / \mathrm{l}$; Ph values between 7.20 to 8.10 degrees ;total ammonia (NH3) between 0.25 to $0.43 \mathrm{mg}$. / nitrile (NO3-N) 0.22 to $0.34 \mathrm{mg} / \mathrm{L}$; nitrate (NO2-N) between 0.26 to $0.34 \mathrm{mg} / \mathrm{L}$ and salinity between 2.32 and 2.34 (g./L). Water quality parameters recorded in the present study indicate the experimental ponds water were within the acceptable levels required for growth and development of the tested fish species. These results are in accordance with the findings ofBoyd (1979); Abdelhamid et al. (2000); (Abdelhamid et al., 2002; AbdelHakim et al., 2013).

Effect of fish stocking density on total pond production.

Concerning pond total fish production as affected with fish stocking density, results of Table (12) 
Table 12: Fish production and size grades of fish species Nile tilapia (O. niloticus); Gray mulletPouri (Mugil cephalus) and Tobara ( L. ramada) ,obtained from various treatments (Mean \pm SE).

\begin{tabular}{|c|c|c|c|c|c|c|}
\hline \multirow[b]{2}{*}{ Fish grades } & \multicolumn{2}{|l|}{$\mathrm{T} 1$} & \multicolumn{2}{|l|}{$\mathrm{T} 2$} & \multicolumn{2}{|l|}{ T3 } \\
\hline & $\begin{array}{l}\text { Production } \\
\text { kg/pond }\end{array}$ & $\begin{array}{l}\text { \%of } \\
\text { total }\end{array}$ & $\begin{array}{c}\text { Production } \\
\text { kg/pond }\end{array}$ & $\begin{array}{l}\text { \%of } \\
\text { total }\end{array}$ & $\begin{array}{l}\text { Production } \\
\text { kg/pond }\end{array}$ & $\begin{array}{l}\text { \%of } \\
\text { total }\end{array}$ \\
\hline Supper grade (3/ kg) & $2500.0 \pm 15.2^{\mathrm{b}}$ & 63.32 & $3500.0 \pm 13.2^{\mathrm{a}}$ & 77.48 & $1350.0 \pm 12.10^{c}$ & 28.44 \\
\hline $1^{\text {st }}$ grade $(4-5 / \mathrm{kg})$ & $1050.0 \pm 11.6^{\mathrm{b}}$ & 26.64 & $450.0 \pm 11.3^{\mathrm{c}}$ & 9.95 & $2000.0 \pm 12.11^{\mathrm{a}}$ & 42.14 \\
\hline $2^{\text {nd }}$ grade ( $\left.6-8 / \mathrm{kg}\right)$ & $335.0 \pm 6.50^{\mathrm{b}}$ & 8.51 & $300.0 \pm 8.11^{\mathrm{c}}$ & 6.63 & $1000.0 \pm 8.4^{\mathrm{a}}$ & 21.08 \\
\hline $3^{\text {rd }}$ grade $(9-20 / \mathrm{kg})$ & $57.0 \pm 5.11^{\mathrm{C}}$ & 1.45 & $271.0 \pm 6.11^{\mathrm{b}}$ & 5.95 & $396.0 \pm 5.08^{\mathrm{a}}$ & 8.34 \\
\hline Total Nile tilapia & \multicolumn{2}{|c|}{$3942.0 \pm 1.80^{c}$} & \multicolumn{2}{|c|}{$4521.6 \pm 3.30^{b}$} & \multicolumn{2}{|c|}{$4746.0 \pm 2.13^{\mathrm{a}}$} \\
\hline $\begin{array}{l}\text { Mullet or Bouriyield } \\
\text { (kg/pond) }\end{array}$ & \multicolumn{2}{|c|}{$312.0 \pm 0.23^{\mathrm{C}}$} & \multicolumn{2}{|c|}{$342.0 \pm 0.73^{\mathrm{a}}$} & \multicolumn{2}{|c|}{$329.0 \pm 0.43^{b}$} \\
\hline $1^{\text {st Tobara }(\mathrm{kg})}$ & $700.0 \pm 1.10^{\mathrm{b}}$ & 78.69 & $800.0 \pm 1.60^{\mathrm{a}}$ & 84.49 & $250.0 \pm 2.11^{\mathrm{C}}$ & 27.88 \\
\hline $2^{\text {nd }}$ Tobara (kg) & $189.5 \pm 2.15^{\mathrm{b}}$ & 21.33 & $146.8 \pm 3.10^{\mathrm{C}}$ & 15.50 & $646.7 \pm 4.09^{\mathrm{a}}$ & 72.14 \\
\hline Tobara yield (kg/pond) & \multicolumn{2}{|c|}{$889.5 \pm 6.12^{\mathrm{c}}$} & \multicolumn{2}{|c|}{$946.8 \pm 4.16^{\mathrm{a}}$} & \multicolumn{2}{|c|}{$896.7 \pm 4.18^{b}$} \\
\hline Total yield & \multicolumn{2}{|c|}{$5143.5 \pm 7.12^{\mathrm{C}}$} & \multicolumn{2}{|c|}{$5810.4 \pm 5.12^{b}$} & \multicolumn{2}{|c|}{$5971.7 \pm 3.12^{\mathrm{a}}$} \\
\hline
\end{tabular}

a, b, c,... within each raw bearing the same letters do not differ significantly $\mathrm{P}<0.05$ other wise the do.

$\mathrm{T} 1$ = stocking density 16000 fish / feddan ( 12000 Nile tilapia +3000 Tobara +1000 Bouri) ; T2 = stocking density 19200 fish / feddan (14400 Nile tilapia + 3600 Tobara + 1200 Bouri) and T3 = stocking density 22400 fish / feddan ( 16800 Nile tilapia + 4200 Tobara + 1400 Bouri).

It was found that total tilapia production $\mathrm{kg} /$ feddan for $\mathrm{T} 1$; $\mathrm{T} 2$ andT3 were $3942.0 ; 4521.6$ and $4746.0 \mathrm{~kg}$ / feddan respectively. The super grades of tilapia for the same treatments cited above represented $63.32,77.48$ and $28.445 \%$ of the total pond production, respectively Table (12). The statistical evaluation of total pond production of tilapia show that $\mathrm{T} 2$ production significantly $(\mathrm{P}<0.05)$ the highest production of super tilapia grade (3fish $/ \mathrm{kg}$.) followed in a significantly As presented in the same Table percent of tilapia in grade one (4-5 fish/kg.) of the total pond catch for T1; T2; andT3 were 26.64. 9.55 and 42.14 respectively and results revealed that T3 production significantly $(\mathrm{P}<0.05)$ the highest value of tilapia grade $(1)$ followed in a decreasing significantly order by $\mathrm{T} 1$ and T2, respectively Table (12). The same trend was observed for the production of tilapia grade (2) where the percentages of tilapia grade (2) were 21.08; for T3 and $6.63 \%$ for T2 ana $8.51 \%$ of T3 total pond production concerning tilapia in grade (3) T3 recorded the highest production $(\mathrm{P}<0.05)$ followed in a significantly $(\mathrm{P}<0.05)$ decreasing order by $\mathrm{T} 2$ and $\mathrm{T} 1$ respectively Table (12). As presented in this Table results revealed that the averages total pond production of tilapia (kg/feddan) for T1; T2 and T3 were found to be 3942.0; 4521.6 and $4746.0 \mathrm{~kg}$ /feddan, respectively and T3 recorded significantly $(\mathrm{P}<0.05)$ the highest total tilapia production followed in a significantly $(\mathrm{P}<0.05)$ decreasing order by $\mathrm{T} 2$ and $\mathrm{T} 3$ respectively. These results indicate that the total pond production of tilapia increased with each increase in its stocking density and this is reflected on the fish percentages in each grade thus at T3 the percentage of super grade was the lowest and that of Lowes grades were highest compared to the other treatments with lower stocking density. As presented in Table (12) average total yields (kg/0 kg /feddan of gray mallet (Bouri) for T1; T2; and T3 were 312.0; 342.0 and 329. Kg/feddan respectively. Results of the same Table reveal that Bouri pond production recorded its highest value in T2 $(\mathrm{P}<0.05)$ followed in a significantly decreasing order by T1and T3 respectively. These results in indicate that increasing the Bouri stocking density from 1000 fish/feddan to 1200 fish /feddan resulted in best pond production while increasing the density of Bouri to 1400 fish /feddan may lead to decreasing in the total production while may dealreduced living space effect (Chen and prowse 1964) concerning the pond production for Liza ramada (Tobara) results of Table (12) reveal that averages of total production $\mathrm{kg} / 0 \mathrm{~kg} /$ feddan were $889.5 ; 946.8$ and $896.7 \mathrm{~kg} / 0 \mathrm{~kg}$ 
/feddan for T1; T2 and T3 respectively and the statistical evaluation of results show that $\mathrm{T} 2$ recorded the highest production of Tobara $(\mathrm{P}<0.05)$ followed in significantly decreasing order by T3and T1 respectively. Results of the same Table show as that T2 recorded the highest value of Tobara in grade (1)and the lowest percentage of grade (2)compared in the other treatment grades (Table 12) As presented in the same Table averages of total production $\mathrm{kg} / 0 \mathrm{~kg} /$ feddan from all tested fish species in the present study were 5143.5 ; 5810.4 and $5971.7 \mathrm{~kg} /$ feddan for T1 ; T2 and T3 respectively, and T3 recorded the highest total production followed in a decreasing significantly order by T2and $\mathrm{T} 1$ respectively. These results indicate that the total pond production increased $(\mathrm{P}<0.05)$ with in increasing the stocking density from 16000 to 19200 and to 22400 fish /feddan, however the contribution of fish grades of lower value in the total catch increased which is reflected on the results. The obtained results (Table 12) are in agreement with the findings of results of Hassan and Mahmoud (2011) who tested the effects of stocking density of $1.5 ; 2,0 ; 2.5 ; 10.0$ and 15 fish $/ \mathrm{m} 3$ of polycultured Nile tilapia+common carp+mullet and African catfish reared in earthen pond on average ponds production and found that pond production of the tested species increased with increasing the stocking density of the tested species.

\section{Cost and returns as affect with stocking density of fish}

As presented in Table (13) total cost per experimental pond including the costs of the stocked fingerlings of the tested species and feed costs are presented in Table (13).

Table 13: Costs and returns of the applied treatments

\begin{tabular}{|l|l|l|l|}
\hline Item & T1 & T2 & T3 \\
\hline Fingerlings: & & & \\
Tilapia 220/1000 fingerlings & 2640.0 & 3168.0 & 3696.0 \\
Bouri 2200/1000 fingerlings & 2200.0 & 2640.0 & 3080.0 \\
Tobara 750/1000 fingerlings & 2250.0 & 2700.0 & 3150.0 \\
Total fingerlings costs & 7090.0 & 8508.0 & 9926.0 \\
Feeds: amount price 4.10 LE/ kg & 34165.3 & 40124.65 & 45518.2 \\
\hline Total costs LE & 41255.3 & 48632.65 & 55444.2 \\
\hline
\end{tabular}

Results revealed that the total costs for T1, T2 and T3 were 41255.3, 48632.65 and55444.2LE, respectively. These results indicate that total input costs in form of fingerlings feed indicate with each increase of the stocking density. The percentage of total costs T1 (100\%) was 117.88 and $134.35 \%$ for T2 and T3, respectively. These results indicate that increasing the stocking density by $20 \%$ and $40 \%$ over the traditional stocking density in the study area increased the cost by 17.88 and $34.39 \%$ over the traditional stocking density, respectively. Results of Table (14) illustrate the total pond returns from tilapia, Bouri and Tobara.

Table14: Effect of stocking density a pond fish production and pond income of the tested species

\begin{tabular}{|c|c|c|c|c|c|c|c|}
\hline \multirow[b]{2}{*}{ Returns } & \multirow[b]{2}{*}{ Price/kg/LE } & \multicolumn{2}{|c|}{ T1 } & \multicolumn{2}{|c|}{ T2 } & \multicolumn{2}{|c|}{ T3 } \\
\hline & & Quantity/kg & Income/LE & Quantity/kg & Income/LE & Quantity/kg & Income/LE \\
\hline Tilapia super grade & 11 & 2500 & 27500 & 3500 & 38500 & 1350 & 14850 \\
\hline $1^{\text {ts }}$ grade & 9 & 1050 & 9450 & 450 & 4050 & 2000 & 18000 \\
\hline $2^{\text {nd }}$ grade & 7 & 335 & 2345 & 300 & 2100 & 1000 & 7000 \\
\hline $3^{\text {rdgrade }}$ & 5 & 57 & 285 & 271 & 1355 & 396 & 1980 \\
\hline Total of Tilapia & & & 39580 & & 46005 & & 41830 \\
\hline Gray mullet (Bouri) & 24 & 312 & 7488 & 342 & 8208 & 329 & 7896 \\
\hline $\begin{array}{l}\text { Tobara 1st grade } \\
2^{\text {nd }} \text { grade }\end{array}$ & $\begin{array}{l}18 \\
13\end{array}$ & $\begin{array}{c}700 \\
189,5\end{array}$ & $\begin{array}{c}12600 \\
2457\end{array}$ & $\begin{array}{l}800 \\
146\end{array}$ & $\begin{array}{c}14400 \\
1898\end{array}$ & $\begin{array}{c}250 \\
646.7\end{array}$ & $\begin{array}{l}4500 \\
8407\end{array}$ \\
\hline Total of Tobara & & 15057 & & & 16298 & & 12907 \\
\hline Total & & 5143.5 & 62125 & 5810.4 & 70502 & 5971 & 62606 \\
\hline
\end{tabular}


Results of this Table show that the total incomes of T1;T 2 and T3 were 62125;70502 and $62606 \mathrm{LE}$; respectively. These results indicate that total returns per feddan increased with each increase in the stocking density. These results indicate that the total incomes from fish sales for T2 and T3 were 13.48 and $0.77 \%$ higher than that of T1. The slightly higher income of T3 had due mainly to the fact the T3 produced even more total production but the average weights obtain were low which lowered the sale prices of fish in this treatment. As presented in Table (15) averages of net returns as differences between total production value (LE) for T1, T2 and T3 was 20869. 7; 21869.35 and 7161.9 LE respectively. These results indicate that T2recorded the highest net returns followed by T1 and T3, respectively. Averages net returns over total costs as percentage of total costs were 50,59; 44,97 and 12, $92 \%$ for $\mathrm{T}_{1} ; \mathrm{T}_{2}$ and $\mathrm{T}_{3}$, respectively indicating that the stocking density between 16000 and 19200 fish / feddan from Tilapia , Bouri and Tobara could be recommended to attain higher percentages of net returns to total costs and increasing the density to 22400 fish / Feddan may increased the total pond production but the percentage of higher fish grades decreased which is reflected on the pond income from the saled fish.

Table 15: Costs and returns of the applied treatments

\begin{tabular}{|l|l|l|l|}
\hline \multicolumn{1}{|c|}{ Item } & T1 & T2 & T3 \\
\hline Total costs, LE & 41255.3 & 48632.65 & 55444.2 \\
Total production value, LE & 62125.0 & 70502.0 & 62606.1 \\
Net returns & 20869.7 & 21869.35 & 7161.9 \\
\hline Total production kg & 5143.5 & 5810.4 & 5971.7 \\
\hline \%Net returns over costs & 50.590 & 44.970 & 12.920 \\
\hline
\end{tabular}

$\mathrm{T} 1$ = stocking density 16000 fish / feddan $(12000$ Nile tilapia +3000 Tobara +1000 Bouri) ; T2 = stocking density 19200 fish / feddan ( 14400 Nile tilapia +3600 Tobara +1200 Bouri) and T3 = stocking density 22400 fish / feddan ( 16800 Nile tilapia +4200 Tobara +1400 Bouri).

There results are in partial agreement with the findings of Hassan and Mahmoud (2011) who reported that the rate of return to capital (\%) for earthen ponds stocked with Nile tilapia ; common carp ; silver carp; mullet and African catfish at densities of $70 ; 15 ; 1.5 ; 2$ and 2.5 fish $/ \mathrm{m}^{3}$ were $28.99 ; 12.64 ; 62.02 ; 59.45 ; 50.45$ and same authors concluded that the semi-intensive culture system $\left(2.5 \mathrm{fish} / \mathrm{m}^{3}\right)$ was the most profitable system.

\section{REFERENCE}

Abdel-Hakim, N.F.; Al-Azab, A.-D.A.; Allam, H.Y.H.; Toulan, A.E.; El-Wahsh, M.H.M. (2013). Studies on fertilization sources with artificial feeds on productivity of earthen ponds stocked with different fish species. . Egypt. J. Aquat. Biol. \& Fish. 17 (1): 35-53.

Abdel-Hakim, N.F.and Ammar, A.A. (2005). Effect of stocking density on growth performance and pond productivity of Nile tilapia (Oreochromis niloticus) cultured in earthen ponds. Egypt. J. Aquat. Biol. \& Fish. 9(4):127-144.

Abdel-Hakim, N.F.; Hilali, I.A.; Khalil, M.H. and Al-Azab, A.A. (2001). Effect of stocking density and feeding rate on performance of Nile tilapia (Oreochromis niloticus) reared in Tanks. Egyptian J. Nutrition and Feeds (Special Issue), 705-717.

Abdel-hakim, N.F. and Salah, A.-e.A. (2008). Effect of initial stocking size and production cycle on growth performance of mono sex tilapia reared in earthen ponds. $8^{\text {th }}$ International Symposium on Tilapia in Aquaculture 255-269. 
Abdelhamid, A.M.; Khalil, F.F.M. and Seden, M.A.A. (2000). Possibility of using dried live yeast and lacto-sacc in Nile tilapia fingerlings diets. J. Agric. Sci. Mansoura Univ. 25: 4905-4911.

Abdelhamid, A.M.; Sallam, A.E.; Abd Allah, G.A. and El-Samra, S.H. (2002). Effect of feeding male rats on aflatoxic diets without or with medicinal herbs (thyme, safflower, ginger, black cumin, and/or garlic). Proc. $2^{\text {nd }}$ Conf. on Food borne Contamination and Egyptian's Health, Mansoura Fac. Agric., pp. 99-121.

Abou Zied, R.; El-Maksoud, A.A. and Ali, A. (2005). Effect of stocking rates of Nile tilapia (Oreochromis niloticus L.) and grey mullet (Mugil cephalus L.) on their performance in polyculture earthen ponds. Annals of Agric. Sci., 43(3): 1057-1066.

Abou Zied, R.and Hassouna, M. (2007). Effect of meagre (argyrosomus regius) stocking rate on nile tilapia and grey mullet production that reared in earthen ponds under polyculture system. Annals of Agric. Sci. , 45 (1): 121-132.

Aksungur, N.; Aksungur, M.; Akbulut, B. and Kutlu, I. (2007). Effects of stocking density on growth performance, survival and food conversion ratio of turbot (psetta maxima) in the net cages on the southeastern coast of the Black Sea. Turkish J. Fish. \& Aquat. Sci., 7:147-152.

Ammar, A.A. (2009). Effect of initial weight and stocking density on growth performance of mono sex nile tilapia reared in semi intensive system. Egypt J. Aquat. Biol. \& Fish., 13(2):69-80

AOAC International. (1990). Official methods of analysis of AOAC International. In: (U.S.), A.o.O.A.C. (Ed.). AOAC International, Gaithersburg, Md., pp. CD-ROMs.

APHA, (1998). Standard methods for the examination of water and wastewater. Prepared and published jointly by American Public Health Association, American Water Works Association, and Water Pollution Control Federation., Washington, DC.

Bíró, P. (1995). Management of pond ecosystems and trophic webs. Aquacult., 129: 373386.

Boyd, C.E., 1979. Water quality in warm water fish pond. Craft Master printers, INC, Opelika Alabama.

Chakraborty, S.B.and Banerjee, S. (2010). Effect of Stocking Density on Monosex Nile Tilapia Growth during Pond Culture in India. World Acad. Sci. Engin. \& Technol., 68:1511-1515.

Chang, W.Y.B. (1988). Fish production: Data synthesis and model development. Collaborative Research Support Program (CRSP), pond dynamic. Aquaculture 6th annual administrative report, Oregon State University, Oregon, USA, pp. 41-49.

Chen, F.Y. and Prowse, G.A. (1964). The effect of living space on the growth rate of fish Ichthyologica 3:11-20.

Coche, G. (1976). A general review of cage culture and its application in Africa. In: FAO (Ed.), FAO Technical Conference on Aquaculture. Kyoto (Japan).

Danaher, J.J.; Tidwell, J.H.; Coyle, S.D.; Dasgupta, S. and Zimba, P.V. (2007). Effects of Two Densities of Caged Monosex Nile Tilapia, Oreochromis niloticus, on Water Quality, Phytoplankton Populations, and Production When Polycultured with Macrobrachium rosenbergii in Temperate Ponds. J. World Aquacult. Soc., 38:367382.

De Silva, S.S.and Anderson, T.A. (1995). Fish nutrition in aquaculture. Springer.

El-Dahhar, A.; Nagdy, Z.; Amer, T. and Ahmed, M. (2006). Effect of dietary protein level and stocking ratios of striped mullet (Mugil cephalus) and Nile tilapia (Oreochromis niloticus) in polyculture system in net enclosures on growth performance and feed utilization. J. the Arabian Aquacult. Soc., 1 (2): 1-18.

El-Kotamy, A.-A.M.Y. (2008). Studies on semi-intensive fish culture in earthen ponds. Faculty of Agiculture. Al-Azhar Cairo. 
El naggar, G.O.; Ibrahim, N.A.and Zead, M.Y.A.(2008). influence of fertilizers'types and stocking density on water quality and growth performance of Nile tilapia-african catfish in polyculture system. $8^{\text {th }}$ International Symposium on Tilapia in Aquacult., 157-171.

Florence, O.N.and Harrison, T. O. (2012). Impact of Stocking Density on the Polyculture of Clarias gariepinus and Oreochromis niloticus. J. Agricult. Sci. \& Technol., 2(A):1018-1023.

GAFRD, (2012). Statistics of fish production Ministry of Agriculture and Land Reclamation,Cairo.

Green, B W.; El Nagdy, Z. and Hebicha, H. (2002). Evaluation of Nile tilapia pond management strategies in Egypt. Aquaculture Research 33:1037-1048.

Hassan, A.A.-R. and Mahmoud, A.A.-F. (2011). Effect of stockig density on growth performance and economic retern in semi-intensive and extensive fish culture methods in earthen ponds. j. Arabi.Aquacult. soc., 6(1): 13-32.

Hassouna, M.M.E.; El-Maksoud, A.M.S.A.; Radwan, M.S.M. and El-Rahman, A.A.A. 1998. Evaluation of three commercial feeding regimes for Nile tilapia , Oreochromis niloticus L., reared in earthen ponds. Egyptian J. Anim. Prod. 35 Suppl., 267-277.

Hung, S.S.O.; Lutes, P.B.; Shqueir, A.A. and Conte, F.S. (1993). Effect of feeding rate and water temperature on growth of juvenile white sturgeon (Acipenser transmontanus). Aquacult., 115: 297-303.

Khattab, Y.A.R.; Abdel-Tawwab, M. and Ahmad, M.H. (2004). Effect of protein level and stocking density on growth performance, survival rate, feed utilization and body composition of Nile tilapia fry (Oreochromis niloticus L. In: Bolivar, R., Mair, G., Fitzsimmons, K. (Eds.), Sixth International Symposium on Tilapia in Aquaculture, Manila, Philippines, BFAR, Philippines, pp. 264-276.

Liu, K.M. and Chang, W.Y.B. (1992). Bioenergetic modelling of effects of fertilization, stocking density, and spawning on growth of the Nile tilapia, Oreochromis niloticus (L.). Aquaculture Research 23: 291-301.

Lutz, C.G. (2003). Polyculture: principles, practices, problems and promise. Aquacult. Mag., 29: 34-39.

Malecha, S.R.; Buck, D.H.; Baur, R.J. and Onizuka, D.R. (1981). Polyculture of the freshwater prawn, Macrobrachium rosenbergii, Chinese and common carps in ponds enriched with swine manure: I. Initial trials. Aquacult., 25:101-116.

Mahmoud, H. K. E. (2012). Effect of same managerial and enviroumental factors on fish performance ph.D Thesis Faculity of Agricultuer, Zagazig University.

Milstein, A. and Svirsky, F. (1996). Effect of fish species combinations on water chemistry and plankton composition in earthen fish ponds. Aquacult. Res., 27: 79-90.

Moustafa, E.T. (1993). Studies on factors affecting productive performance of tilapia nilotica raised in cages. Faculty of Agriculture. AL-Azhar Univrrsity, Cairo.

NRC, (1993). Nutrition requirement of fish, Committee on Animal Nutrition, Board on Agriculture. National Academy Press, Washington, DC.

Shang, Y.C. (1990). Aquaculture Economic Analysis: An IntroductionShang. Louisiana State University, , Baton Rouge, L.

SPSS Inc. (2008). SPSS advanced statistics 16 update. SPSS, Inc., Chicago, Ill., USA.

Steel, R.G.and Torrie, J.H. (1980). Principles and procedures of statistics, a biometrical approach. McGraw-Hill Kogakusha, Ltd., USA.

Swingle, H.S. (1956). Arepressive factor controlling reproduction in fishes Proc. Pacif. Sci Congr. , 8(3):865-871.

Wohlfarth, G.W.; Hulata, G.; Karplus, I. and Halevy, A. (1985). Polyculture of the freshwater prawn Machrobrachium rosenbergii in intensively manured ponds, and 
the effect of stocking rate of prawns and fish on their production characteristics. Aquacult., 46:143-156.

\title{
ARABIC SUMMRY
}

\section{أثر معدلات التسكين فى نظم الإستزراع السمكى المشترك على أداء النمو للأسماك المستزرعة وإنتاجية الأحواض الترابية}

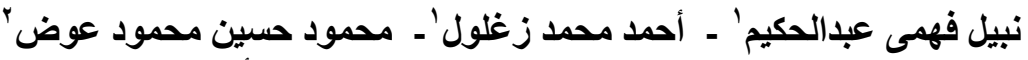

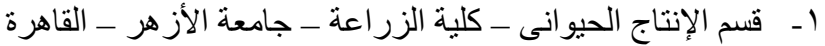

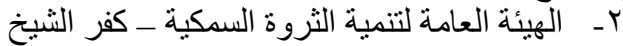

تم إجر اء هذه الدر اسة فى مزر عة سمكية خاصة بمنطقة طلمبات Vـ الرياض محافظة ـ كفر الثيخ شمال دلتا

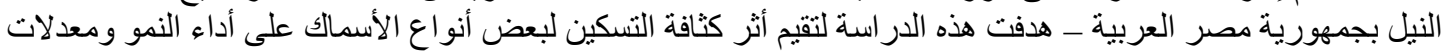

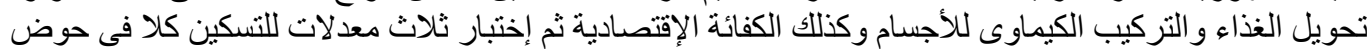

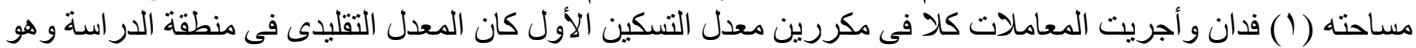

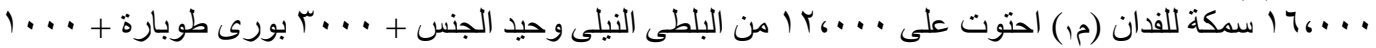

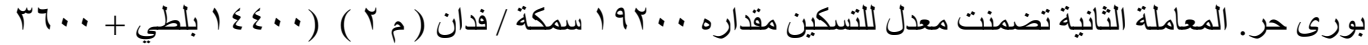

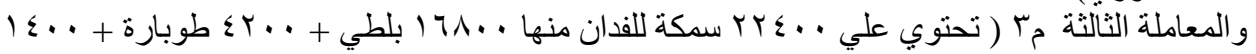

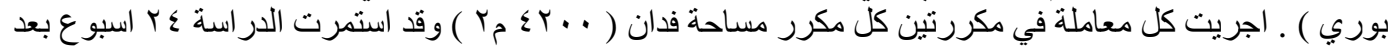
بدايتها.

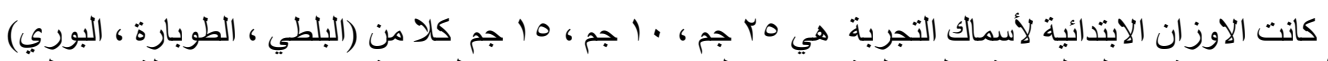

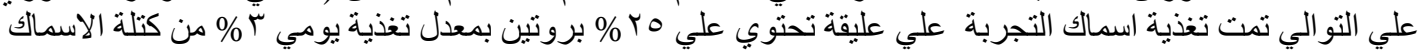

تم تقديم العليقة علي وجبتين متساويتين يوميا الاولي الساعة · ا ل صباحاً والثانية الساعة ب من بعد ظهر اليوم تم

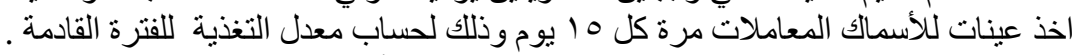

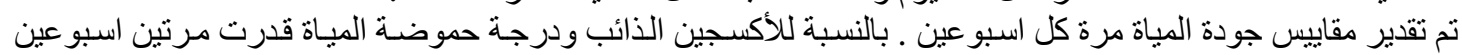

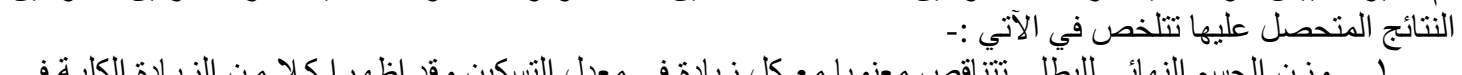

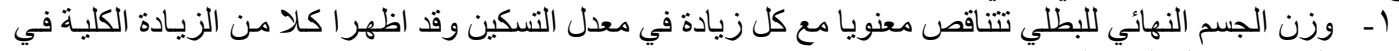

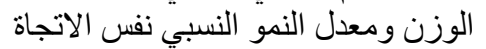

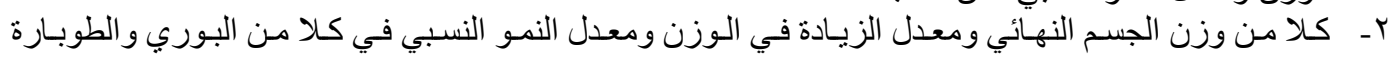

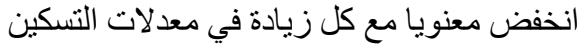

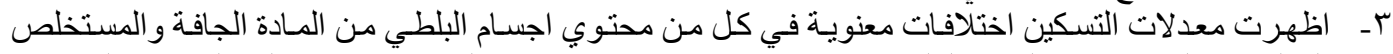

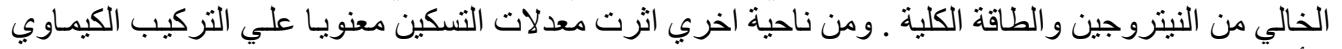

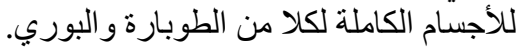

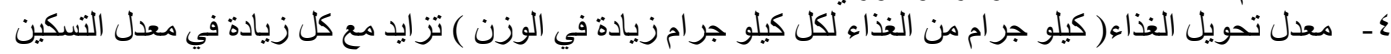

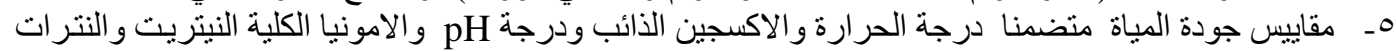

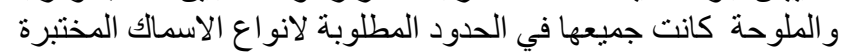

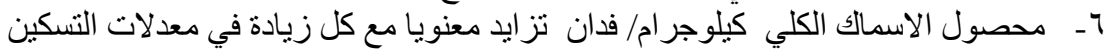

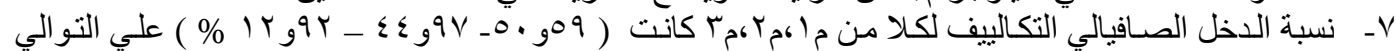

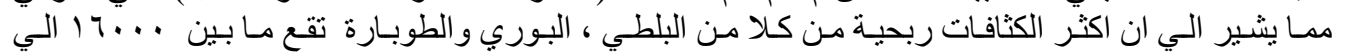

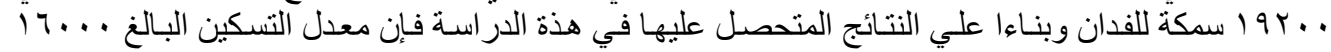

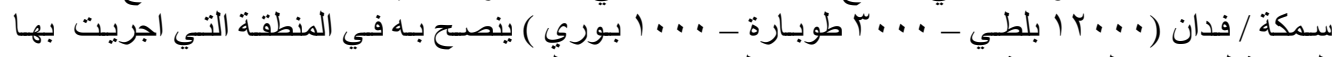

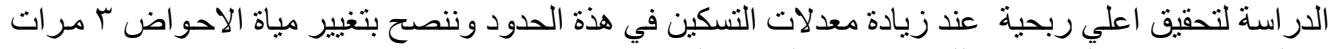
منتالية مع استخدام التهوية وكذلك معدلات عالية من التغذية. 